\title{
Early detection of influenza virus in cell culture by means of immunofluorescence
}

\author{
A. F. M. S. RAHMAN \\ From the Public Health Laboratory and Department of Microbiology, Central Middlesex Hospital, London
}

SYNOPSIS An indirect fluorescent antibody technique using human serum for the rapid detection of influenza A virus in monkey kidney cell cultures is described.

Influenza A2 virus was isolated from 38 of 88 nose/throat swabs received from patients with suspected influenza during the winter of 1971-72.

Thirty-two strains isolated in monkey kidney cell cultures were identified by immunofluorescence on the day haemadsorption was observed, 22 of them within a week of receipt of the specimen.

Human antiserum was found to be very satisfactory for this purpose.

One of the first applications of immunofluorescence for the rapid diagnosis of respiratory virus infections was for influenza using virus-infected cells obtained from nasal washings (Liu, 1956). Several workers have reported the rapid identification of respiratory viruses in cell cultures by the direct fluorescent antibody (FA) technique using animal serum (Chin, Walton, and Liu, 1964; Tomlinson, Chinn, and Curtis, 1969; McQuillin, Gardner, and McGuckin, 1970). Hers, van der Kuip, and Masurel $(1968,1971)$ used human serum in an indirect fluorescent antibody (IFA) test for the same purpose. To obtain exceptionally rapid results, they tested monkey kidney cells by immunofluorescence 36 hours after inoculation with clinical specimens and, in later experiments, 16 hours after inoculation without testing for haemadsorption. However, the elaborate methods described were beyond the scope of a small virus laboratory offering a comprehensive diagnostic service. Chin et al (1964) and Tomlinson et al (1969) performed haemadsorption tests before the FA test from the third day after inoculation.

In this paper a modified immunofluorescence technique is described. This technique enables haemadsorbing agents isolated in monkey kidney cell cultures to be identified without the need for more elaborate and time-consuming procedures such as complement-fixation, neutralization, and haemagglutination-inhibition tests. The haemadsorption test was delayed until four to six days after inoculation to secure a greater proportion of isolations on first testing. On cell cultures showing positive haemadsorption, IFA staining was performed with pooled convalescent human antiserum Received for publication 8 May 1973. to influenza A virus and sheep antihuman immunoglobulin labelled with fluorescein (Wellcome Reagents Ltd). This procedure was economical in monkey kidney cells and in technicians' time.

This report presents results of immunofluorescence tests and virus isolations from nose/throat swab specimens received from patients with suspected influenza at home or in hospital in north-west London during four months from December 1971 to March 1972.

\section{Materials and Methods}

Methods used, except that of the IFA technique, were those followed routinely in this laboratory.

VIRUS ISOLATION

Throat swabs were received in virus transport medium, $0 \cdot 1 \mathrm{ml}$ of the medium was inoculated into each of two tubes of monkey kidney cells and into the amniotic cavity of three 10-day-old fertile hen's eggs. The tubes, on a roller, and the eggs were incubated at $33^{\circ} \mathrm{C}$. Specimens received two passages in monkey kidney and one in eggs before reporting any specimen as negative.

HAEMADSORPTION AND HAEMAGGLUTINATION A haemadsorption test was performed on monkey kidney cell cultures after four to six days' incubation. The medium from the first tube in each pair was removed to the second tube for further tests and $1 \mathrm{ml}$ of a suspension of $0.04 \%$ human group $\mathrm{O}$ red cells was added to the first tube. After keeping for 20 minutes at $+4^{\circ} \mathrm{C}$ in a sloping position the tube was inspected microscopically for adsorption of red cells. 
Egg fluids-amniotic and allantoic-were harvested after 72 hours' incubation and tested for the presence of haemagglutinin to human group $\mathrm{O}$ red cells and to fowl red cells.

\section{IMMUNOFLUORESCENCE PROCEDURES}

\section{Preparation of smears}

When a tube showed haemadsorption, the cells were scraped with a Pasteur pipette from the wall of the tube and sedimented by centrifugation. Four smears of the centrifuged deposit were made on a microscopic slide so as to give an almost confluent sheet of cells spread over an area of approximately $3 \mathrm{~mm}$ diameter; two were treated with human antiserum to influenza $\mathrm{A}$ virus and the other two with negative control serum. Two additional smears were made on the same slide from uninfected monkey kidney cells of the same batch. These were treated with human antiserum. The smears were dried in air and fixed in acetone at room temperature for 10 minutes. Smears of monkey kidney cells infected with a Hong Kong/68 strain of influenza A2 virus were included with each test as a positive control. Such smears were prepared in quantity and stored at $-20^{\circ} \mathrm{C}$ for up to eight weeks ready for use.

\section{Sera}

Because it was readily available, pooled human convalescent serum with a high titre of complementfixing antibody to soluble influenza $\mathbf{A}$ antigen was used; it did not contain any detectable complement-fixing antibodies to influenza $\mathbf{B}$, parainfluenza, or mumps viruses. At its use dilution (1 in 100) fluorescence was not demonstrable on monkey kidney cell preparations infected with these haemadsorbing viruses and with Simian virus 5 . The human antiserum was freeze-dried in $0.2 \mathrm{ml}$ amounts. An ampoule of $0.2 \mathrm{ml}$ was reconstituted to 10 times working strength in phosphate-buffered saline $(\mathrm{pH} \mathrm{7.4)}$ and stored in $0.5 \mathrm{ml}$ quantities at $-40^{\circ} \mathrm{C}$. Before use one aliquot was thawed rapidly in a water bath at $37^{\circ} \mathrm{C}$, diluted to working strength and kept at $+4^{\circ} \mathrm{C}$ for daily use.

A human serum free of complement-fixing antibody against the above mentioned viruses served as negative control serum.

Fluorescein-conjugated antihuman immunoglobulin (sheep) from Wellcome Reagents Ltd was used for IFA staining. A 'chessboard' titration of antiserum and conjugated immunoglobulin was done with monkey kidney cells after 72 hours' infection with influenza A2 virus to determine the use-dilution of each reagent. Dilutions showing bright fluorescence without any unwanted staining in the controls were used routinely.

\section{Indirect fluorescent antibody staining}

Stage 1: the unlabelled antiserum and the negative control serum were layered on appropriate smears o $\overrightarrow{\overrightarrow{5}}$ cells and incubated in a plastic box at roonz temperature for 15 minutes. The slides were thero washed for three minutes in gently running tap water with a final rinse in distilled water and dried $\widehat{\oplus}$

Stage 2: conjugated immunoglobulin was applieç to the smears which were then incubated and washed? as in stage 1. Preparations were mounted in $\bar{P}$ Polarfluor B of $\mathrm{pH} 8.5$ (supplied by Polaron $\overrightarrow{\mathrm{w}}$ Instruments Ltd, London).

\section{Fluorescence microscopy}

The preparations were examined at $\times 100$ magnifi cation by means of a Union $\mathrm{MiC} \mathrm{Bi}$ inverted microir scope with 150 watt tungsten halogen lamp Tiyoda super-wide dark field condenser, and allo dielectric interference filter (Heimer and Taylor? 1972).

\section{Results}

There were $38(43 \%)$ isolations of influenza A2 virus from 88 nose/throat swabs. The immunofluorescence and virus isolation results are shown in the table

\begin{tabular}{|c|c|c|c|c|c|}
\hline \multirow{2}{*}{$\begin{array}{l}\text { No. of } \\
\text { Positive } \\
\text { Isolations }\end{array}$} & \multicolumn{2}{|c|}{ System of Isolation } & \multicolumn{2}{|c|}{$\begin{array}{l}\text { Presumptive } \\
\text { Identification }\end{array}$} & \multirow{2}{*}{$\begin{array}{l}\text { Confirmed by } \\
\text { Virus Reference } \\
\text { Laboratory, } \\
\text { Colindale }\end{array}$} \\
\hline & $\begin{array}{l}\text { Monkey } \\
\text { Kidney }\end{array}$ & $\begin{array}{l}\text { Fertile } \\
\text { Eggs }\end{array}$ & $I F A$ & $H A$ & \\
\hline 20 & $\ldots$ & $\ldots$ & - & + & 20 \\
\hline 12 & $\ldots$ & - & $\perp$ & ND & 12 \\
\hline 6 & - & & ND & $\therefore$ & 6 \\
\hline 38 & 32 & 26 & 32 & 26 & 38 \\
\hline
\end{tabular}

Table Isolation and identification results of Influenza A2 virus from 88 nose/throat swabs

IFA $=$ indirect fluorescent antibody test $\mathbf{H A}=$ haemagglutination 0 test $; \mathrm{ND}=$ not done

Thirty-two strains isolated in monkey kidney cellos were stained by the IFA technique on the day that haemadsorption was observed. The reading of the amount of fluorescence was very subjective but the results were recorded according to the following scheme:

\begin{tabular}{lll}
\hline $\begin{array}{l}\text { Amount of } \\
\text { Fluorescence }\end{array}$ & Recording & Interpretation \\
\hline Bright & - & Positive \\
Definite & - & $\begin{array}{l}\text { Positive } \\
\text { Positive if controls are all right, } \\
\text { Faint }\end{array}$ \\
otherwise repeat \\
Doubtful & $=\}$ & Negative \\
\hline
\end{tabular}


Positive and negative controls should give readings of $++++1+++$ or ++ and \pm or - respectively. There were no false positive or negative results. However, one fluorescence preparation was difficult to read because of bacterial contamination in the cell culture but repeated culture gave positive fluorescence after two days of incubation. All the agents isolated were identified by the Virus Reference Laboratory, Colindale, as Hong Kong/68 variants of influenza A2 virus. Simian haemadsorbing viruses were not encountered because batches of monkey kidney cells showing simian virus cytopathic effect in pilot cultures were excluded. Six strains of influenza $\mathrm{A}$ virus were isolated in eggs only, 12 in monkey kidney cells only, and 20 in both eggs and monkey kidney cells.

The time required for isolation and identification of 32 strains in monkey kidney cells ranged between four days and three weeks, but $22(68 \%)$ were isolated and identified within a week of receipt of the specimen.

\section{Discussion}

In spite of many published works on the successful application of immunofluorescence, direct or indirect, for identifying agents isolated in cell culture, immunofluorescence is not practised routinely by many diagnostic virology laboratories. The availability of adequate but slow conventional methods for isolating viruses and a lack of urgency to identify them due to lack of antiviral chemotherapy may explain this reluctance to adopt a FA test as a preferred method in clinical virology. Moreover, until recently, neither conjugated animal sera nor conjugated anti-species immunoglobulin suitable for diagnostic immunofluorescence in virology were available from commercial sources.

When an agent is isolated in cell culture, the conventional procedures usually require several passages to enhance the virus titre sufficiently to perform neutralization, complement-fixation, or haemagglutination-inhibition tests for its identification. This takes longer, requires more work, and is more costly. Rapid identification of any agent isolated in cell culture not only saves cost, time, and labour, but also may prevent the patient, particularly those with respiratory viral illnesses, from being given unnecessary antibacterial drugs. With these thoughts in mind I have adopted immunofluorescence as a routine diagnostic tool for rapid identification of agents isolated in cell cultures, particularly haemadsorbing viruses.

I decided to use human serum with a high specific complement-fixing antibody titre in an IFA test. The advantages of using human serum are that hightitre sera are easily available to any laboratory doing virus serology and may be used in a FA technique. Moreover, as the serum is type-specific, new antigenic variants of influenza virus will be detected. A potential disadvantage is that the serum may contain antibodies to other viruses, but usually interference by unwanted antibodies may be avoided in the test by dilution or absorption. From experience gained in the course of this work, human serum appears to be adequately sensitive and specific. The IFA test using human serum has been successfully applied in this laboratory for detecting mumps virus, herpesvirus hominis, and adenovirus in cell cultures. For recognition of an outbreak, cell cultures may be examined by a FA technique at $24 / 48$ hours after incubation. Influenza $A$ virus may be detected in monkey kidney cell culture by immunofluorescence as early as $\mathbf{1 6}$ hours after inoculation before any cytopathic effect is apparent or the haemadsorption test is positive (Hers et al, 1971).

I thank Dr C. E. D. Taylor for his advice and encouragement; Mr G. V. Heimer for supplying the sera; Mr D. J. Smith and Miss L. Mitchell for their help.

\section{References}

Chin, T. D. Y., Walton, E. R., and Liu, C. (1964). Rapid identification of influenza and parainfluenza viruses isolated in tissue cultures by immunofluorescence. Bact. Proc., 64, 86.

Heimer, G. V., and Taylor, C. E. D. (1972). Improved immunofluorescence obtained with a tungsten halogen lamp in a modified inverted microscope. J. clin. Path., 25, 88-93.

Hers, J. F. P., van der Kuip, L., and Masurel, N. (1968). Rapid diagnosis of influenza-experience in a winter outbreak Lancet, 1, 510-511.

Hers, J. F. P., van der Kuip, L., and Masurel, N. (1971). Rapid diagnosis of respiratory virus infection in infected tissue cultures. Ann. N.Y. Acad. Sci., 177, 70-77.

Liu, C. (1956). Rapid diagnosis of human influenza infection from nasal smears by means of fluorescein-labeled antibody. Proc. Soc. exp. Biol. (N.Y.), 92, 883-887.

McQuillin, J., Gardner, P. S., and McGuckin, R. (1970). Rapid diagnosis of influenza by immunofluorescent techniques. Lancet, 2, 690-695.

Tomlinson, A. H., Chinn, I. J., and Curtis, G. D. W. (1969). The use of fluorescent antibody in the diagnosis of influenza. Bull. Wld Hlth Org., 41, 295-296. 